\title{
QUANTITATIVE POTENTIAL FOR INSTALLATION OF SOLAR COLLECTORS IN JOZEFOW, POLAND
}

\author{
Karol Tucki, Anna Baczyk, Mateusz Mitoraj \\ Warsaw University of Life Sciences, Poland \\ karol_tucki@sggw.pl
}

\begin{abstract}
The aim of the research was to determine the quantitative potential for installation of collectors and/or solar panels to be mounted on buildings in Józefów, a small town near Warsaw. We calculated the energy yield and ecological performance of the investment, including reduced emission of carbon dioxide and other gases that contribute to air pollution. Additionally, the study had a social aspect, too. A survey was carried out among residents of municipalities, with an aim to measure general environmental awareness as well as the respondents' attitude to RES/energy technologies and willingness to install solar devices on their buildings or within their properties. In the first part of the survey, $49 \%$ of respondents showed interest in electricity production technologies, $16 \%$ were interested in thermal energy, while further $35 \%$ of respondents were eager to try hybrid systems, which are a combination of the two. In the opinion of respondents, the most popular electricity production technology is the one based on photovoltaic panels (95\%), while the best known method of thermal energy production is with the use of solar collectors. The analysis of the surveys carried out allows us to select the preferred renewable energy technologies from among all available for use in Józefów. The second part of the survey was conducted on a group of people, who showed interest in renewable energy technologies and willingness to mount this type of installations on their buildings or properties in part one. They were asked about their preferred type of energy (thermal or electric), the current use of renewable sources, technical data of the building (type of the roof, etc.) and data needed to perform calculations (number of users of the facility or the average annual electricity consumption). As a result of the study, 91 properties potentially suitable for the installation of RES were identified.
\end{abstract}

Keywords: photovoltaic panel, ecological effects, ecological awareness, solar collectors.

\section{Introduction}

The energy system currently in use in Poland is mainly based on conventional energy sources, which is largely attributable to the coal monoculture, which has prevailed in Poland for years $[1 ; 2]$. Nevertheless, through the implementation of the European Union regulations and domestic legal deeds, the monoculture is gradually being replaced by renewable energy sources [3-6].

Józefów is a municipality with urban buildings, public utility buildings, detached residential houses and block of flats playing a major role in the landscape. Three nature reserves are located within the area (the Świder Reserve, the Wyspy Zawadowskie Reserve and the Wyspy Świderskie Reserve). Due to the close proximity of residential buildings and nature reserves, technologies based on wind have not been taken into account, as they generate too much noise. Given the hydrological conditions within the municipality, indicating that the potential of this source of energy is low, water power was excluded from the analysis, too. Furthermore, due to the low potency of geothermal power (168 thousand Tpu $\mathrm{km}^{-2}$ ) [7] and the presence of protected areas, thermal power was also considered inappropriate for use within the municipality. As Józefów does not have its own wastewater treatment plant and there are no animals of the porcine species or cattle, there is no possibility to to use biogas as a substrate to produce power.

Józefów municipality is located within an area with the average total annual amount of insolation of c.a.1100 $\mathrm{kWh} \cdot \mathrm{m}^{-2}$ [8] and the average yearly sunshine of approximately $1600 \mathrm{~h}$ [9]. These values, rather moderate when compared to the national level, are enough to produce electrical power from solar energy with the use of photovoltaic panels and to produce heat with the use of solar collectors. Additionally, the installations can be mounted on roofs of the existing facilities, which is an asset given the large number of residential buildings in the municipality. In light of the analyses above, it was decided that solar energy makes the best source of renewable energy for the Józefów municipality. Additionally, photovoltaic panels and/or solar collectors will integrate best with the town infrastructure, as their impact on the landscape is negligible. Installed on roofs of already existing facilities, they will not significantly interfere with the look of the town. Next to the analysis of natural conditions and assessment of the general infrastructure of the municipality, social research needs to be carried out. Where decentralised production of renewable energy is planned, attitude of the society is 
equally important as climatic constraints. The residents need to agree, or even show willingness, to mount the systems within their own properties and on their own buildings.

The aim of the study is to present an assessment of the potential of decentralised production of renewable energy within the Józefów municipality, understood as small household installations and installations mounted on public utility buildings, based on the social and environmental analyses carried out.

\section{Material and Methods}

The study was focused on one specific municipality as the implementation of the Low Carbon Economy Plan introduces minor, yet visible and discernible, changes for the better in its immediate natural environment. The Józefów municipality, which has been subjected to analysis, is located to the south-east of Warsaw. The choice fell to this area because it lies in central Poland and is characterised by national average values of the factors that have impact on the performance of renewable sources of energy. Additionally, preliminary analyses show that the interest in RES in the area selected is high.

In order to verify the general attitude of the local community to renewable energy, a survey was carried out on a representative group of 500 residents of the municipality. The respondents were asked, among others, about their interest in the specific types of RES technologies (production of electrical energy, heat or hybrid devices), and the preferred electrical energy or heat production RESbased technologies.

Energy calculations concerning the energy yield of photovoltaic panels and solar collectors, as well as the ecological effects of the solutions proposed, were performed. All computations were based on the parameters of the model $\mathrm{pV}$ panel (Table 1). As polycrystalline panels perform better under scattered radiation, it was this type of cells that was used in the analysis.

Parameters of a model photovoltaic panel

Table 1

\begin{tabular}{|l|c|}
\hline \multicolumn{1}{|c|}{ Parameter } & Value \\
\hline Rated power, $\mathrm{Wp}$ & 275 \\
\hline Module performance, $\%$ & 16.8 \\
\hline Dimensions, mm & $1650 \times 941 \times 35$ \\
\hline Weight, $\mathrm{kg}$ & 18.6 \\
\hline Off-load voltage, $\mathrm{V}$ & 38.5 \\
\hline Short-circuit current, A & 9.25 \\
\hline Number of cells & 60 \\
\hline Area of a single cell, $\mathrm{m}^{2}$ & 1.46 \\
\hline
\end{tabular}

The inclination of photovoltaic panels that was considered optimum for the latitude, where the facilities are located, was established at $35^{\circ}$ [11]. Calculations were based on data concerning a typical meteorological year for the Warsaw Okęcie station

Based on the data presented above and on a catalogue data concerning the adopted photovoltaic panel model, the estimated energy yield from one panel within the model installation (power rating $1.1 \mathrm{~kW}$ ) was calculated. The computations were performed based on formula (1):

$$
W=\frac{E \cdot \eta \cdot S}{1000}
$$

where $W$ - estimated energy yield, kWh;

$E$ - the average annual insolation in Poland, $1000 \mathrm{kWh} \cdot \mathrm{m}^{-2}$;

$\eta$ - panel performance \%;

$S-$ area of cells, $\mathrm{m}^{2}$.

The average annual coverage of power needs at the level of $50 \%$ was assumed for the purpose of calculations of the energy yield on solar collectors. The calculations were based on the parameters of a model flat solar collector (Table 2). 
Key parameters of a model vacuum solar collector

Table 2

\begin{tabular}{|l|c|}
\hline \multicolumn{1}{|c|}{ Parameter } & Value \\
\hline Dimensions, $\mathrm{mm}$ & $2020 \times 1037 \times 87$ \\
\hline Gross area of the collector, $\mathrm{m}^{2}$ & 2.095 \\
\hline Active area (aperture), $\mathrm{m}^{2}$ & 1.818 \\
\hline Liquid capacity, 1 & 1.1 \\
\hline Weight (less liquid), $\mathrm{kg}$ & 40 \\
\hline Optical efficiency, $\%$ & 80.2 \\
\hline First-order coefficient $a_{1}, \mathrm{Wm}^{-2} \cdot \mathrm{K}^{-1}$ & 3.8 \\
\hline Second-order coefficient $a_{2}, \mathrm{Wm}^{-2} \cdot \mathrm{K}^{-2}$ & 0.0067 \\
\hline
\end{tabular}

Energy computations and simulations for the systems were all performed with the use of proSOLAR 2.0 software. The input data used by the software included: (1) catalogue data of flat collectors, (2) climatic data from the weather station, (3) data specific to the facility, (4) assumptions concerning water parameters and distribution of collectors.

Insolation of the surface of collectors will be the same as in the part concerning photovoltaic panels. Average daily consumption of hot water equals 50 litres per person.

Computations concerning the required number of collectors assume $1.1-1.5 \mathrm{~m}^{2}$ of aperture per person for flat collectors and $0.8-1.0 \mathrm{~m}^{2}$ for vacuum collectors. The recommended ratio of water tank capacity in the system to the area of collectors, allowing to ensure heat reserve for 1-2 days of opaque sky cover, equals 50-80 litres for each $\mathrm{m}^{2}$ [10].

\section{Results and Discussion}

A sizeable percentage of respondents (49\%) show interest in hybrid installations, meaning installations that can be used for production of both electrical energy (35\%) and heat $(16 \%)$. The production of heat and electricity can be ensured through the use of technologies based on diversified sources.

The analysis showed that the majority of respondents would indicate solar energy (represented by photovoltaic cells) as the technology that could be used to produce power (95\%). Solar energy (collectors), in turn, seems to be the preferred solution for the production of heat (78\%).

Based on the above-mentioned climate and nature analyses, the preliminary assessment of the infrastructure and the social survey conducted, it was decided that solar energy would be the best source for production of both electrical and thermal energy. The concept assumes development of a proposal to mount the installations on private facilities owned by those who are willing to participate in the investment and on the roofs of five public utility buildings indicated by the Town Council.

The installations proposed will have a significant influence on the structure of energy use by facility 3 , ensuring the production of over $92 \%$ of the electric power needed. For facilities 1,4 and 5 the coverage of the overall demand for electrical energy from photovoltaics reaches $30-50 \%$. The lowest coverage was reported for facility 2 , even though the installation mounted thereon is the biggest of all. This is because of the building's huge demand for power, i.e. of $1624.45 \mathrm{MWh}$ per year. The photovoltaics in question will reduce the consumption of electrical energy by all the facilities and indirectly lead to reduced emission (Table 3 ).

Surveys conducted among the residents of Józefów show that owners of 120 facilities are interested in the installation of photovoltaics and/or solar collectors on the roofs of their houses, with 90 buildings left after the environmental analysis.

The calculations were performed for a representative building, the resident of which does not currently use any renewable energy technologies and produces hot water with the use of coal. In the first place, the number of the solar collectors needed was established. In the case analysed (4 users), the aperture footprint should equal $4.8-6.0 \mathrm{~m}^{2}$. Three collectors were selected to satisfy this requirement, of the total aperture footprint of $5.454 \mathrm{~m}^{2}$. According to previous calculations, annual yield on one photovoltaic panel equals $259 \mathrm{kWh}$. With the annual consumption of electricity of 
$6428 \mathrm{kWh}, 25$ panels are needed, of the total area of c.a. $39 \mathrm{~m}^{2}$. The overall power rating of the proposed number of panels equals $6875 \mathrm{~W}$, which translates into a yield of $6475 \mathrm{kWh}$.

Table 3

Annual energy yield on the facilities and demand coverage

\begin{tabular}{|c|c|c|c|c|c|}
\hline Facility & $\begin{array}{c}\text { Installation } \\
\text { footprint, } \\
\mathbf{m}^{\mathbf{2}}\end{array}$ & $\begin{array}{c}\text { Number of } \\
\text { panels } \\
\text { in the } \\
\text { installation }\end{array}$ & $\begin{array}{c}\text { Annual } \\
\text { yield of } \\
\text { electrical } \\
\text { energy, } \\
\mathbf{k W h}\end{array}$ & $\begin{array}{c}\text { Annual demand } \\
\text { for electrical } \\
\text { energy, kWh }\end{array}$ & $\begin{array}{c}\text { Demand coverage } \\
\text { by the } \\
\text { installations } \\
\text { proposed, \% }\end{array}$ \\
\hline Facility 1 & 324.5 & 209 & 57075.9 & 107476 & 50.3 \\
\hline Facility 2 & 652.1 & 420 & 108669.3 & 1624450 & 6.7 \\
\hline Facility 3 & 154.7 & 119 & 30789.6 & 33290 & 92.5 \\
\hline Facility 4 & 155.3 & 100 & 25873.6 & 85391 & 30.3 \\
\hline Facility 5 & 164.6 & 106 & 27426.1 & 63196 & 43.4 \\
\hline TOTAL & 1481.2 & 954 & 246834.7 & 1913803 & - \\
\hline
\end{tabular}

Solar collectors shall cover $86.57 \%$ of demand for d.h.w. in summer and c.a. $21.5 \%$ in winter. The annual coverage shall therefore equal $55.55 \%$.

The installation of photovoltaic panels is designed in such a way as to cover $100 \%$ of annual consumption of electricity. Nevertheless, due to the climate in which the facility is located, most of the energy shall be produced in summer. Surplus energy shall then be accumulated and whenever shortages occur, the facility will be able to collect free of charge $80 \%$ of the energy given up as part of surplus production.

As the consumption of electricity in a typical household is similar all year round (Fig. 1), the monthly demand was averaged to $536 \mathrm{kWh}$.

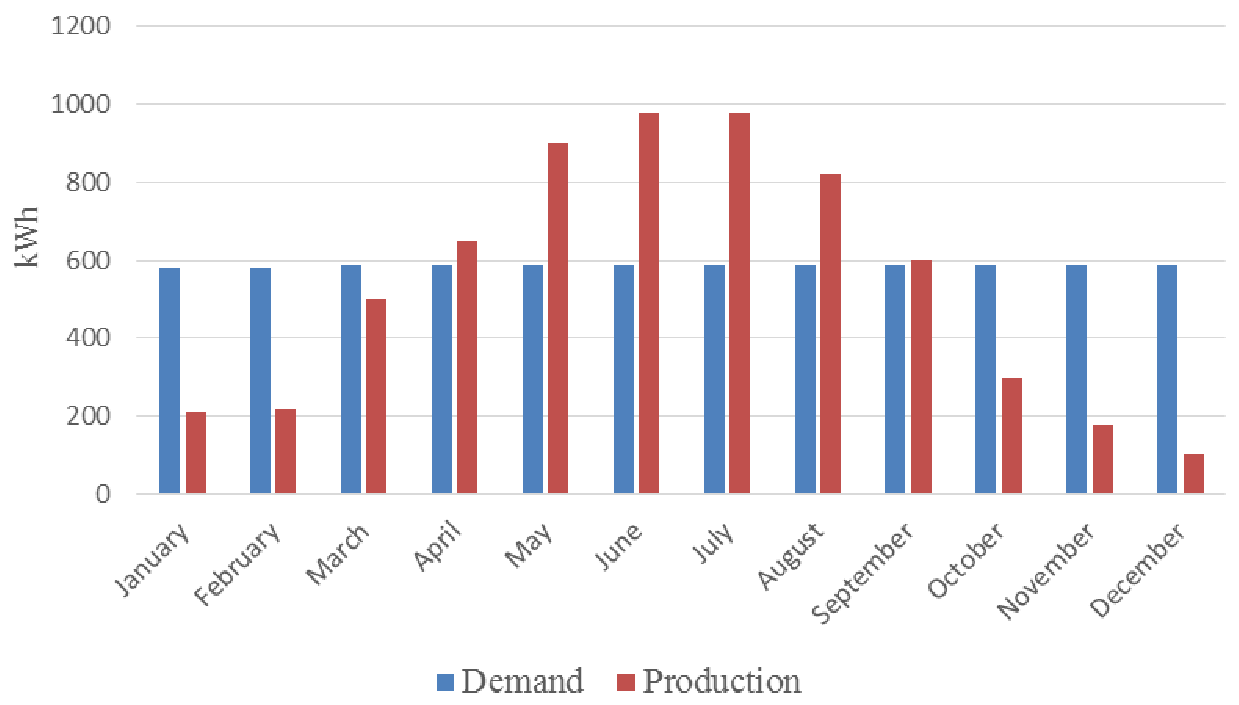

Fig. 1. Yield on installation vs. demand of facility

Another element of the study was calculation of the ecological effect of installation of photovoltaic panels and solar collectors for the selected building, on the basis of actual data given in reference literature (Table 4).

Table 1

Emissions avoided through the use of photovoltaic panels and solar collectors

\begin{tabular}{|l|c|c|c|c|c|c|}
\hline Parameter, kg & $\begin{array}{c}\text { Sulphur } \\
\text { oxides }\end{array}$ & $\begin{array}{c}\text { Nitrogen } \\
\text { oxides }\end{array}$ & $\begin{array}{c}\text { Carbon } \\
\text { monoxide }\end{array}$ & $\begin{array}{c}\text { Carbon } \\
\text { dioxide }\end{array}$ & $\begin{array}{c}\text { Total suspended } \\
\text { particles (TSP) }\end{array}$ & $\begin{array}{c}\text { Benzo- } \\
\text { apyrene }\end{array}$ \\
\hline $\begin{array}{l}\text { Photovoltaic } \\
\text { panels }\end{array}$ & 9.45 & 5.94 & 1.46 & 4972.74 & 0.39 & - \\
\hline Solar collectors & 3.886 & 0.971 & 27.322 & 1168.769 & 3.795 & 0.0085 \\
\hline
\end{tabular}


Similar calculations were carried out for the remaining facilities, including public utility buildings (Table 5)

Table 5

Total ecological effect of the use of photovoltaic panels and solar collectors

\begin{tabular}{|l|c|c|c|c|c|c|}
\hline Parameter, kg & $\begin{array}{c}\text { Sulphur } \\
\text { oxides }\end{array}$ & $\begin{array}{c}\text { Nitrogen } \\
\text { oxides }\end{array}$ & $\begin{array}{c}\text { Carbon } \\
\text { monoxide }\end{array}$ & $\begin{array}{c}\text { Carbon } \\
\text { dioxide }\end{array}$ & $\begin{array}{c}\text { Total suspended } \\
\text { particles (TSP) }\end{array}$ & $\begin{array}{c}\text { Benzo- } \\
\text { apyrene }\end{array}$ \\
\hline $\begin{array}{l}\text { Total private } \\
\text { buildings }\end{array}$ & 800.8158 & 482.8791 & 1280.169 & 420162.6 & 163.1372 & 0.226143 \\
\hline $\begin{array}{l}\text { Total public } \\
\text { utility buildings }\end{array}$ & 296.6557 & 186.5904 & 45.87657 & 156134.6 & 12.1438 & - \\
\hline
\end{tabular}

\section{Conclusions}

As part of the study, installation of 954 photovoltaic panels on public utility buildings was proposed, of the overall installed capacity of $262.36 \mathrm{~kW}$. The installations to be mounted on private buildings encompass a total of 1840 photovoltaic panels of the installed capacity of $506 \mathrm{~kW}$ and 228 solar collectors.

Based on the calculations performed, it was possible to obtain quantitative information concerning avoided emissions and volumes of power produced by the installations. The Low Carbon Economy Plan for the town of Józefów sets forth the following objectives oriented on low emission and efficient use of natural resources:

- greenhouse gas emissions abatement until 2020 by $3139 \mathrm{Mg}$ CO2 yearly (3.5\%), when compared to the basal year 2010 ,

- consumption of final energy in individual sectors of energy recipients until 2020 reduced by 10489 MWh (4.3\%), when compared to the basal year 2010,

- renewable energy source contribution in the gross final consumption of energy increased until 2020 by $452 \mathrm{MWh}$, when compared to the basal year 2010 .

Based on the objectives above and the results of the calculations carried out, the ecological effect of the installations proposed and basic assumptions of the Low Carbon Economy Plan were compared. In the basal year 2010, the overall final energy consumption was at the level of app. 224,500 MWh, with the total $\mathrm{CO} 2$ emission of c.a. $95,100 \mathrm{Mg} \mathrm{CO} 2$ per year.

The total of emissions avoided owing to the installations proposed to be mounted on public utility buildings and private facilities shall equal $576.3 \mathrm{Mg} \mathrm{CO} 2$ per year, i.e. $18.36 \%$ of the value assumed in the Low-Carbon Economy Plan, with the reduction reaching $0.6 \%$.

This study encompasses assessment of a broadly defined potential for decentralised production of renewable energy sources. The following conclusions were drawn on the basis of the analyses and deliberations carried out as part of the research:

1. The potential for decentralised production depends on a number of factors such as regulatory environment, environmental constraints, social attitude and individual properties of the facilities.

2. The deliberations, surveys and computations performed permitted us to define the potential of the municipality to use renewable energy, in the form of solar radiation, in decentralised production. The results are as follows: (1) public utility buildings: 954 photovoltaic panels of the total installed capacity of $262.35 \mathrm{MW}$ and annual yield of $246 \mathrm{MWh}$, (2) private facilities: 1,840 photovoltaic panels of the total installed capacity of $506 \mathrm{~kW}$ and annual yield of $476.56 \mathrm{MWh}$, plus 228 solar collectors.

3. With the installations proposed, it will be possible to avoid the following emissions: $1097.47 \mathrm{~kg}$ of sulphur oxides, $669.47 \mathrm{~kg}$ of nitrogen oxides, $1,326.05 \mathrm{t}$ of carbon monoxide, $576.30 \mathrm{t}$ of carbon dioxide, $175.28 \mathrm{~kg}$ of total suspended particles and $0.23 \mathrm{~kg}$ of benzoapyrene.

4. The solutions proposed will make the objectives set in the Low Carbon Economy for the town of Józefów feasible. 


\section{References}

[1] Kulczycka J., Lipińska A.: Barriers to liberalisation of the Polish energy-sector. Applied Energy. Vol. 76, Issues 1-3, September-November 2003, pp. 229-238.

[2] Paska J., Sałek M., Surma T.: Current status and perspectives of renewable energy sources in Poland. Renewable and Sustainable Energy Reviews. Vol. 13, Issue 1, January 2009, pp. 142-154.

[3] Directive 2009/28/EC of the European Parliament and of the Council of 23 April 2009 on the promotion of the use of energy from renewable sources and amending and subsequently repealing Directives 2001/77/EC and 2003/30/EC. [online] [22.04.2018]. Available at: http://eurlex.europa.eu/legal-content/EN/TXT/PDF/?uri=CELEX\%3A32009L0028\&from=EN

[4] Krajowy Plan Działania w zakresie energii ze źródeł odnawialnych (The National Action Plan for energy from renewable sources). Ministerstwo Gospodarki (Ministry of Economy). [online] [22.04.2018]. Available at:

http://www.me.gov.pl/Energetyka/Odnawialne+zrodla+energii/Krajowy+plan+dzialan (In Polish)

[5] Plany Gospodarki Niskoemisyjnej (National Program for the Development of a Low-carbon economy). Ministerstwo Gospodarki (Ministry of Economy), 2015. [online] [22.04.2018]. Available at: http://www.konsultacje.gov.pl/sites/default/files/projectfiles/Narodowy\%20Program\%20Rozwoju\%20Gospodarki\%20Niskoemisyjnej_1.pdf (In Polish)

[6] Ustawa z dnia 20 lipca 2017 r. o zmianie ustawy o odnawialnych źródłach energii (Act of 20 July 2017 amending the Act on Renewable Energy Sources), SEJM, 2017. [online] [22.04.2018]. Available at: http://prawo.sejm.gov.pl/isap.nsf/download.xsp/WDU20170001593/O/D20171593.pdf (In Polish)

[7] Węglarz A., Kaniszewska A., Łazarowicz A., Ammol-Gostkowska D., Jurczuk E. Plan Gospodarki Niskoemisyjnej dla miasta Józefowa, (The low-emission Economy Program for the city of Józefów) Krajowa Agencja Poszanowania Energii S.A, (The Polish National Energy Conservation Agency), 2016, pp. 1-88. [online] [22.04.2018]. Available at: http://jozefow.bip.eur.pl/public/get_file_contents.php?id=344726 (In Polish)

[8] Globalne nasłonecznienie na płaszczyźnie poziomej - Mapa nasłonecznienia na terenie Polski (Global insolation in the horizontal plane. Map of insolation within the territory of Poland) [online] [22.02.2018]. Available at: http://www.gsfotowoltaika.pl/fotowoltaika/mapanaslonecznienia-polski/ (In Polish)

[9] Mapa rocznego usłonecznienia na terenie Polski z wielolecia 1971-2000 (Map of annual insolation within the territory of Poland for the years 1971-2000). [online] [22.02.2018]. Available at: http://old.imgw.pl/klimat/ (In Polish)

[10] Smolec W. Fototermiczna konwersja energii słonecznej (Photothermal conversion of solar Energy). PWN. 2000. pp. 125-377. 